\title{
Umbul Card: A Traditional Game as Nutrition Education Media among Elementary School Students
}

\author{
Ambar OKTAVIA ${ }^{1}$, Helfi AGUSTIN ${ }^{2}$
}

\section{ARTICLE INFO}

\section{Article History:}

Received 03.03.2019

Received in revised form

14.11.2019

Accepted

Available online 01.01.2020

\begin{abstract}
The study aimed to determine the feasibility of developing the Umbul Card as an alternative media to create a fun learning atmosphere for students. This is a qualitative research, the method used was Research and Development (R\&D) level 3, carried out to the design revision stage. The instrument used was a validation sheet. The results of the development were carried out by experts, nutritional and media experts, also validated by the user. The results of the study (1) the design of the contents of the material for the development of children's Umbul Card into a nutrition education media score with a percentage of $100 \%$ which was included in the very feasible category. (2) the design of the development of the children's game Umbul Card into a nutritional education media score with a percentage of $92.30 \%$ included in the very feasible category. (3) the validation of the user obtained a score of $92.50 \%$ included in the very feasible category.
\end{abstract}

(C) IJERE. All rights reserved

Keywords: ${ }^{1}$

A traditional game, learning media, education, nutrition

\section{INTRODUCTION}

The nutritional status of students is an important factor to achieve educational goals, if the students are undernutrition, they could not concentrate while studying (Crosby, Jayasinghe and McNair, 2013; Santanu Ghosh, Rakshit and Bhattacharya, 2013). Elementary school students need adequate nutrients as a building material for growth, provide energy needs for physical activity, help maintain the body's resistance to infection and ensure the availability of nutrients in the body for growth needs(Wedu, Pamungkasari and Anantanyu, 2018). Students who have undernourished for a long time will affect their health status, so they are often absent from school. As a result, the school will not be able to fulfil its main mission in providing effective and efficient education (Jomaa, McDonnell and Probart, 2011). Indonesia still has nutritional problems (Riskesdas, 2013). These problems have an impact on the learning achievement and physical growth of elementary school children. The data shows that there were $3.5 \%$ of students are very thin, $6.7 \%$ of students are thin, and $8.0 \%$ of students are obese.

Elementary School students often make snacks as a substitute for main food. Some studies stated that 98.9\% of Indonesian children had snacks at school (BPOM, 2013; Marisa and Nuryanto, 2014). Many students have poor snack behaviour, consume a lot of carbohydrates and consume less fruit (Wang et al., 2018). Students can be deficient in vitamin A, vitamin C, iron, calcium and zinc due to unbalanced nutritional menu, thus affecting children's physical growth and intelligence (Rohmah and Iriyani, 2016).

Nutrition education for children in primary school is very important because good nutritional knowledge will affect attitudes so that children's eating patterns will change and food intake will be better (Zulaekah, 2012). According to Lawrence Green theory, behaviour or a healthy lifestyle can be influenced by the degree of health. Health behaviour can be improved through health education. Nutrition knowledge will help children to be positive and influence their habits in choosing healthy foods.

Study habit is a form of action that is done repeatedly and regularly so that formed an attempt to gain knowledge and in the student's change from not knowing to know. New habits are formed only when people know what to do (knowledge), how to do (skills), and desire to do (motivation). Therefore, in the process of developing Student Habits need a strategy to develop the Habits of Student Learning (Hidayati and Ismail, 2018). In general, government Elementary schools in Indonesia have implemented a thematic curriculum. Where subjects were combined in modules according to the theme. Healthy Food Module and the Healthy Module Nutrition were studied in class V and VI. The learning method was a classic way in the classroom, an unpleasant method for some students. Instead, active learning through the media and the

${ }^{1}$ Corresponding e-mail: helfi.agustin@ikm.uad.ac.id, orcid.org/0000-0003-1589-8637, Ahmad Dahlan University 
delivery of interesting material can be received more easily. Teachers need to innovate in choosing methods and designing fun learning strategies, of course, this requires creative ideas. The learning process that is carried out actively and fun is expected to be more effective in achieving the learning goals that have been set previously. One type of approach in active learning is a methodological approach that is through games so the teaching and learning process becomes fun (Mulyatiningsih, 2010)

Indonesian children have a variety of tradisional games. One of them is the Umbul Card, a guessing games using a picture card for playing. This picture card can be a visual media that is suitable for the development of nutrition education media for elementary school students. Learning media with Umbul cards will prioritize elements of the game, by the characteristics of elementary school children who love to play and the use of cards is already familiar among students, so it is easier to play. The use of play media that they usually use in their daily lives will be easier for children to follow the rules of the game. The picture has the advantage that students will be clearer about a subject or material delivered by the teacher (Hamida et al, 2012). The principle of drawing games must pay attention to several criteria such as pictures, material content, writing size, and colour so that it will increase the level of liking and acceptability (Perdana et al, 2017)

The advantage of this Umbul Card game is easy for children to use, builds excitement and social life in children. The weakness of this media is that it cannot be played alone and must use a facilitator. Independent and fun learning was the reason the Umbul Card is suitable for learning media in the classroom.

\section{Aim of the Study}

Aim of the present study is to determine the feasibility of developing a traditional Umbul Card game as an alternative nutritional education media that was fun for students.

\section{METHOD}

This study is qualitative research, using Research \& Development Level 3. The flow of the research can be seen in Figure 1.

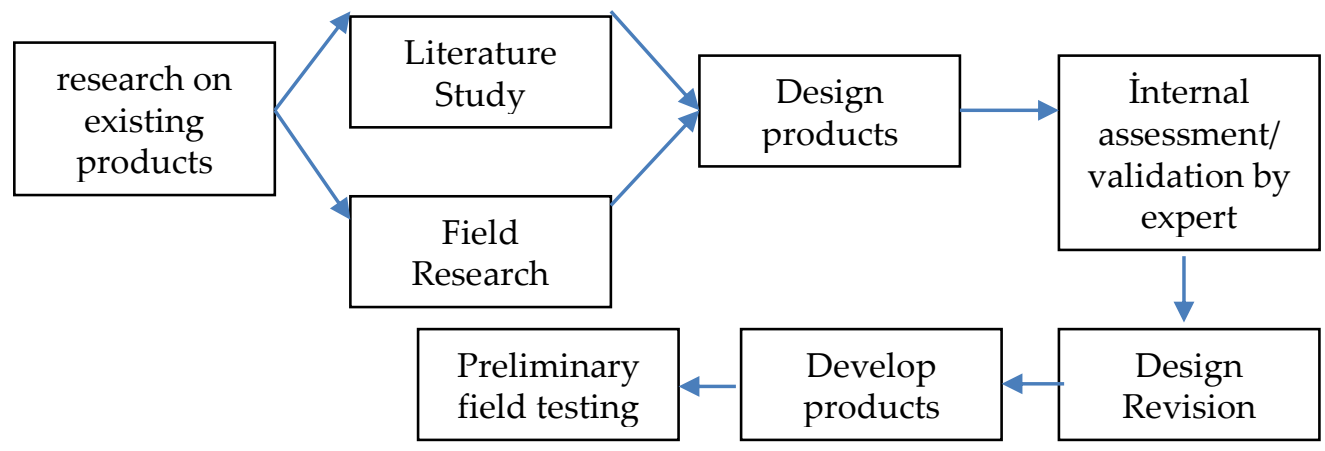

This study modified the Umbul card product, a traditional Indonesian children's game, to be a fun learning medium for students. Research and development functions to develop products by updating existing products, so they become more practical, effective, and efficient (Sugiyono, 2017). Learn specifically how to play the existing umbul cards and their advantages if used as a medium of learning. The first step in level 3 development research begins with studying the literature on nutritional problems in students and the stages of changing nutritional behaviour of students, conducting preliminary research on learning methods that have been carried out. The second step is to study the original Umbul card products, to find out their strengths and weaknesses. The third stage the researchers made a product design that is perfecting/developing original Umbul card products into learning media. Finally, the design of Umbul card products that have been developed will be validated by people who are considered experts.

\section{Material}

The first step researchers defining the existing product fit by studying nutrition material in Healthy Food Module and the Healthy Module Nutrition and find out the situation and learning methods commonly used by teachers. After that, nutrition materials at school were matched by the material on a pocketbook 
made the Ministry of Health. After defining the suitability of target needs into the product, researcher designing the new Umbul card based on Umbul card existing. The design starts by choosing pictures that will be used in the "Umbul" Card. Researchers get these images from the internet by matching them according to the intent and purpose of the material. Nutrition materials at school include 7 indicators; 1 ) consume enough vegetables and fruits, 2) eat high protein side dishes 3) want to eat a variety of staple foods 4) limit foods that are salty, sweet and high in fat 5) drink enough water that is safe for consumption 6) washing hands with soap under running water 7) doing sports.

\section{Data Analyses}

The design of Umbul card products that have been developed will be validated by experts. The validation sheet was prepared to study the feasibility of developing a Umbul Card game into a nutrition education medium for students. Experts provide assessments and suggestions for improving product design by checking the validation sheet. Assessment Indicators consist of the appropriateness of media forms with the development of student psychologists, suitability of color selection, ease of use of media, accuracy of use of materials used, accuracy of use used, politeness in language use, creativity in media development of Umbul Cards, clarity of images on media Umbul cards, images attractiveness to the Umbul media card, structure and design of the media, practicality. Nutritionist validation sheet indicators were aspects of the appropriateness of the contents of the suitability of Umbul card material with the age of the child, the clarity of the language used in the Language Suitability Card with the level of students, interesting according to aspects of presentation of the material, according to the request accordingly, the image supports the contents of the material. Analysis of the data used for media validation was obtained based on a Likert scale calculation with 5 categories; very poor (score 1 ) to very good (score 5 ).

The user validation sheet is the instrument used to determine the user's response to the product being developed. The user validation indicator consists of a review of the media display, between students becoming more active, fun and easy to use, preferably students to the nature of the game that can be used as a learning experience. While the media feasibility test was analyzed with the Guttman scale by giving score 1 if the students answered "yes" and score 0 if the students answered "no". The total score is score from the expert/total score $\times 100 \%$. The category of eligibility assessment is if $n>80 \%$ of the category is very feasible, $60<\mathrm{n}<80 \%$ of the category of worth, $40<\mathrm{n}<60 \%$ of the category quite feasible, $20<\mathrm{n}<40$ the category is not feasible and $n<20 \%$ of the category very unworthy. Based on validation by experts, researchers improve product design, develop and conduct initial field testing of 5 students in learning activities. The experts and students of Segoroyoso Public Elementary Schools involved can be seen in Table 2 :

Table 2. Informant characteristics

No.

Informant Age Gender Job

\begin{tabular}{|c|c|c|c|c|}
\hline 1 & Ms Annisa Parisudha & 28 years old & Female & $\begin{array}{l}\text { Nutritionist and lecturer } \\
\text { at Ahmad Dahlan University, } \\
\text { Yogyakarta-Indonesia }\end{array}$ \\
\hline 2 & $\begin{array}{l}\text { Mr Muhammad Ragil } \\
\text { Kurniawan }\end{array}$ & (36 years old) & Male & $\begin{array}{l}\text { Media expert and lecturer at } \\
\text { Ahmad Dahlan University, } \\
\text { Yogyakarta-Indonesia }\end{array}$ \\
\hline 3 & Hanifah Salsabila & 10 years old & Girl/Female & Student (class 5) \\
\hline 4 & Aulia & 10 years old & Girl/ Female & Student (class 5) \\
\hline 5 & Arya Nino Pratama & 10 years old & Boy/Male & Student (class 5) \\
\hline 6 & Arin Johan Setiari & 10 years old & Boy/Male & Student (class 5) \\
\hline 7 & Bayu Dwi Anggoro & 11 years old & Boy/Male & Student (class 5) \\
\hline
\end{tabular}




\section{FINDINGS}

1. New Image and function of the Umbul card

Figure 1 and 2 can be seen as the original image of the Umbul Card and which has been developed.

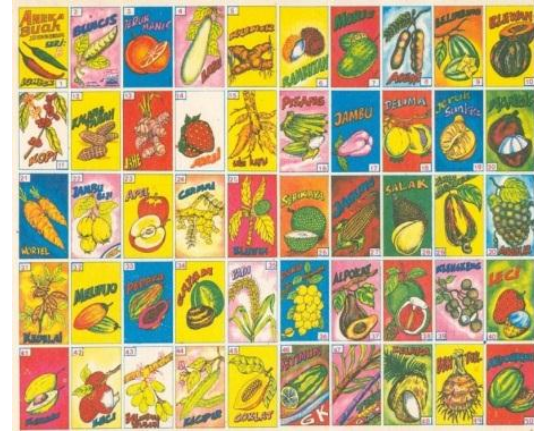

Figure 1. Original "Umbul” Card
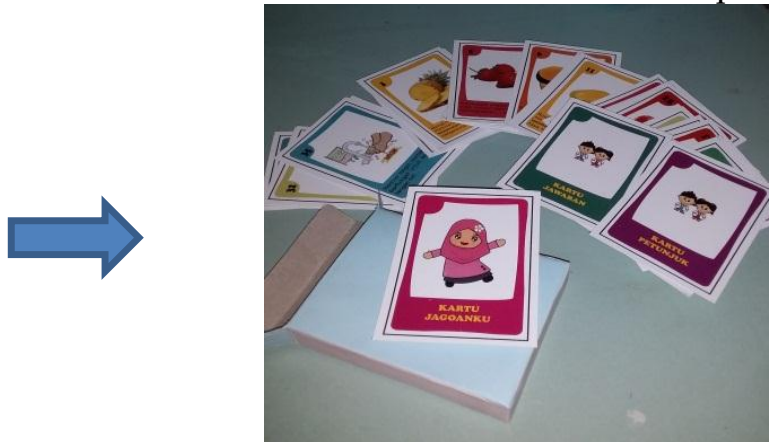

Figure 2. “Umbul” Card after being developed

2. An assessment of the feasibility of the Umbul Card media by media and material experts. The first validation was done on Thursday, June 27, 2019, it was obtained a total score of 51 so that it was known that the obtained value was $78.46 \%$ with the proper category. The second validation was carried out on Monday, July 15, 2019, and the total score was 60 , so it was found that the value obtained was $92.30 \%$ with a very decent category.

3. Improvement. The umbul card has several improvements based on the comments and suggestions of experts during validation.

4. Preliminary field testing

After the umbul card was validated and revised, testing was carried out on users. Validation by the user was done to determine the accuracy of the media and the suitability of the material according to the user. User is the fifth-grade students at Government Elementary School, Pleret Bantul, Yogyakarta.

\section{RESULT, DISCUSSION, AND SUGGESTIONS}

One of the biggest challenges for public health professionals is to analyze existing health problems in the community and choose a behaviour change approach that fits the program's goals (Glanz, Rimer and Viswanath, 2008; Nurse et al., 2014). Malnutrition among students is still a public health problem in Indonesia (Rosso and Arlianti, 2009). Millions of Indonesian children and adolescents remain threatened by staggering rates of stunting and the 'double burden' of malnutrition. One of the behavioural interventions launched by the government is the campaign to eat vegetables and fruit. Accordingly, this study uses an approach to change the awareness of the student for nutrition intervention.

A preliminary study found that teachers have applied active learning methods by using a thematic module. Each student reading the module then filling out questions on the evaluation sheet. This method does not fun and individual. Since by the reason, the researcher predicts Umbul card suitable as a learning media for nutrition education at Elementary school students.

Designing products aims to change the original Umbul products into Umbul Cards for nutritional learning media. The next step is to modify the original image of the Umbul Card into a nutritional learning media. A traditional game played only with a little innovation usually, can be an attractive learning media to students (Isnardiantini, Usodo and Soegiyan, 2019). Corel Draw x6 program is used to design cards. The type of card consists of four; hero card, question card, answer card, and hint card. All types of cards measuring $7.5 \mathrm{~cm} \times 5.5 \mathrm{~cm}$ and using 260-gram ivory paper.

Validation to assess the Umbul Card done by experts. The assessment was conducted in 2 times validation, located on the campus of the Faculty of Public Health, Ahmad Dahlan University. The results are obtained from the validation sheets that have been filled out. The first validation was carried out on Thursday 27 June 2019, obtained a total score of 41 , so that the value obtained was $74.54 \%$ with the proper 
category. The second validation was conducted on Wednesday 10 July 2019, obtained a total score of 55 so that it is known that the obtained value is $100 \%$ with a very decent category.

Based on the results of the validation from material experts and media experts, researchers made revisions based on comments and suggestions both from the media and material sides. The picture shown must be adjusted to the character of elementary school student by considering the level of understanding of children who are still thinking concretely (Patria and Mutmainah, 2018).

The hero card contains a picture who likes to consume nutritious food. The first hero card is a figure named Rara. Rara is a girl wearing a pink hijab. Rara like fruits e.g oranges, mangoes and other fruits. The second hero card is a boy with a red shirt named Bagas. Bagas like vegetables such as spinach, broccoli, carrots and other vegetables. The third hero card is a girl named Aisha. She like her mother's cooking. Her favourite menu is fish and eggs. The fourth hero card is a boy named Dimas. Dimas likes sports and drinks water. The hero card was made as role models for children, so the children were interested and imitating character of his/her idol. This Hero Card changed according to expert advice. The change in background colour selection so that it is not too dark and not too contrasting so that the writing is more clearly legible and looks more attractive.

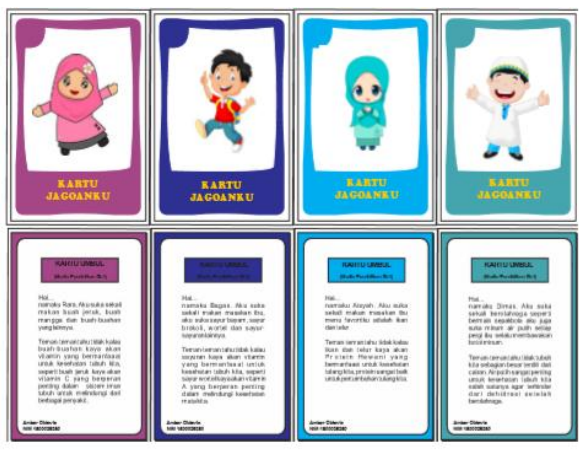

Hero card before revision

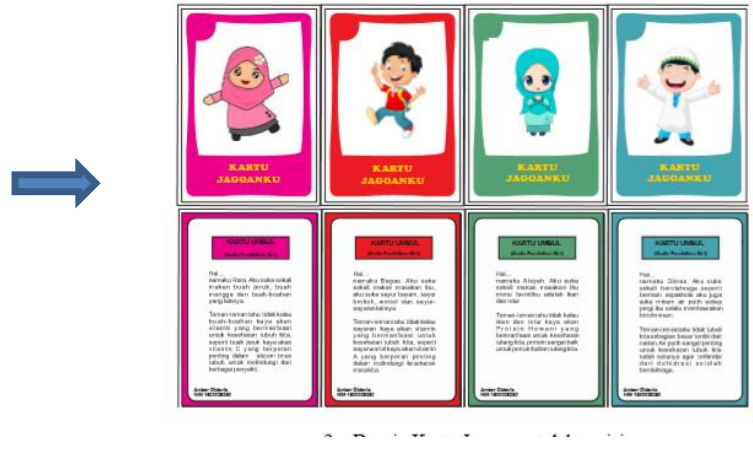

Hero card after revision

The question cards contain pictures of fruits, vegetables, sources of animal protein, sources of vegetable protein, sources of carbohydrates, physical activity, adequate rest, washing hands by soap and the importance of drinking water. The question card contains questions that match the picture. Question cards are created to make it easier for children to understand and easily remember the purpose of the question. The revisions made to the question card are based on expert advice and comments from the media. Changes in the selection of background colours to be brighter and changes in the selection of images that are more in line with their original form, so that the question cards look more attractive and are also easy to read. Suggestions from material experts are questions that are not too difficult and easy to understand.
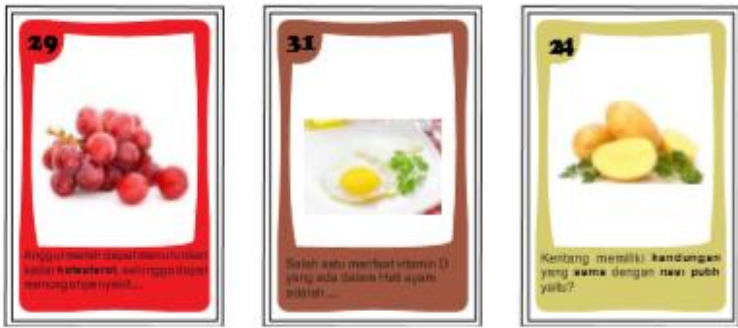

Question card before revision
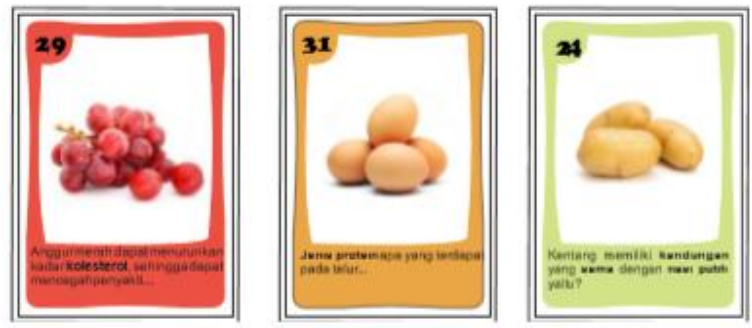

Question card before revision 


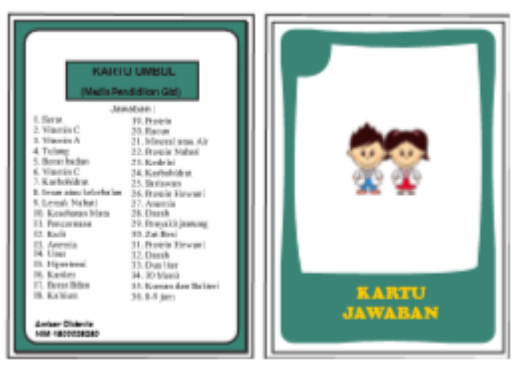

Answer card has no revision

An answer card contains all the answers on the question card. This answer card was only held by the bookie. The answer card was made to help the students when they do not know the answer while playing. The answer card has not been revised. The hint card has been revised based on expert advice and comments from the media side, namely the shape of the card is made like a fold, lighter colour selection, text font size is enlarged so that the game hint card is clearly understood, more beautiful and interesting. This revision is based on expert advice and comments from the material side to increase the age of students who can play using the umbul card so that there is no bias.
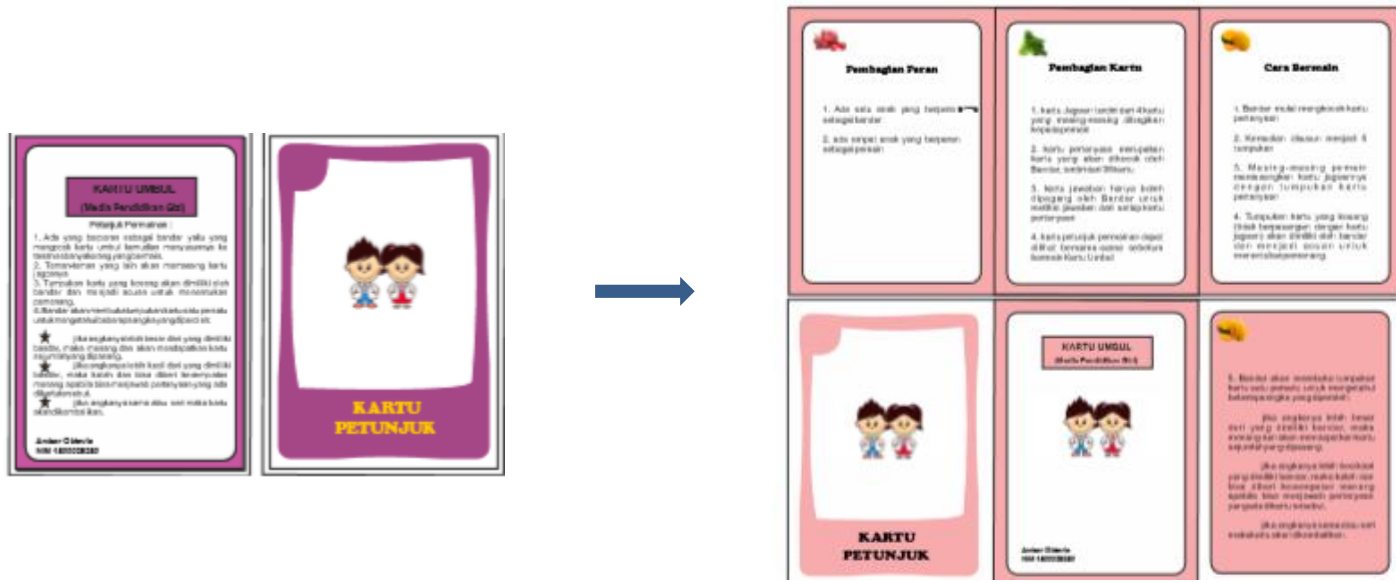

After revising the design, validation was continued with product manufacture, and finally validation by preliminary field testing to the user. User validation was conducted on Monday, July 22, 2019, at the Government Elementary School in Pleret Bantul Yogyakarta. The results of user validation were obtained from the validation sheet that has been filled out by the user. The results of preliminary field testing by user validation obtained a score of $92.50 \%$ with a very decent category. Students were very enthusiastic when given learning by the Umbul Card.
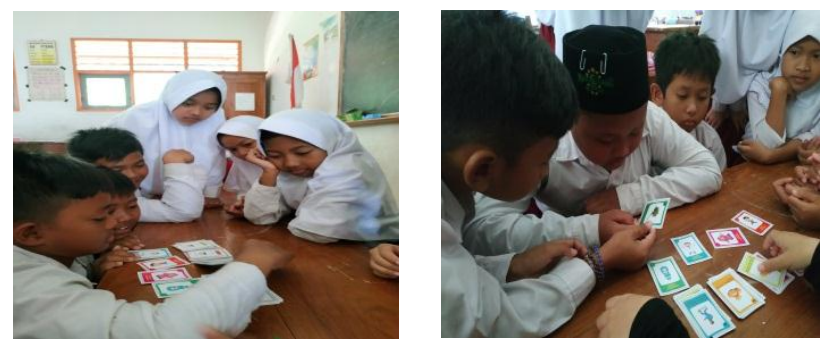

Figure 6. Students were playing Umbul Cards

The technique to play "Umbul" cards is very simple, which starts with a split role. "Umbul" Card Game is played by $2-5$ people. One person plays the role of a bookie who will shuffle the "Umbul" Cards. The other person acts as a member who will pair each card. To start the game, a bookie will be shuffling and then arranging 36 the question cards into 5 piles on the table as many people playing. After that, the other will put their respective cards in front of the pile of question cards. The bookie will open one by one the Umbul Card that has been placed by all of the players to see the numbers obtained. If she/he found the card number 
is bigger/smaller than the other person, the smaller number should answer the question from the question card. On the modified Umbul Card, the question is about nutrition. If he/she can answer correctly, he/she will get a card. If the number of the card was series, the card will be returned and the bookie will be shuffling and arrange the card like the first step.

User validation proves that the Umbul card is effective as a learning medium for elementary school students. Students are more enthusiastic. The enthusiasm of the students' while learning by playing can give a positive response to the teaching and learning process in the classroom (Fadhilah, 2017). The same thing was found in the study (Jin et al., 2018) who find game-based learning methods well received by students. Nutrition education provided by the pictorial card method in the treatment group occurs with two-way communication where it is done face-to-face so that researchers can directly know the response of students who are given nutrition education (Septiana dan Suaebah, 2018). This is supported also by (Komachali, 2012) that the contribution of flashcard vocabulary media in teaching vocabulary to students leads to an increase in higher-level vocabulary. Research result (Eliana and Solikhah, 2013) the media plays an important role in increasing children's nutritional knowledge.

Learning media are all physical tools and all materials that can be used to facilitate teaching and facilities that support student achievement and to facilitate the achievement of learning objectives (Wahidin dan Ahmad, 2018). The media can display information through sound, images, movements, and colours, both natural and manipulated. The material is packaged through a media program, will be clearer, more complete, and attracts interest and is a fun learning tool (Ramdhani and Muhammadiyah, 2015). With the media, presentation material can arouse students' curiosity and stimulate students to react both physically and emotionally. In short, learning media can help students to create a learning atmosphere that is more lively, not monotonous, and not boring (Falahudin, 2014). This is in line with the understanding of the media according to Asnawir and Basyiruddin (Wahidin dan Ahmad, 2018) explain that the media is something that is channelling messages and can stimulate the thoughts, feelings, and will of the audience (students) so that it can encourage the learning process in itself. The media have various types, one of which is visual media that is the media used by relying on sight. According to research (Sunaengsih, 2016), learning media that are packaged attractively will be able to attract the attention of students. Active learning can improve students' cognitive abilities (Zufriady and Kurniaman, 2019). Teachers and students needed interactive multimedia based on the game to support learning activity at primary school. Thus, the teachers were suggested to develop interactive multimedia based on the game by involving experts to produce attractive multimedia and improve learning quality (Saputri, Rukayah and Indriayu, 2018).

Using the traditional game umbul card as nutrition education media makes easier for students to know the health benefits of fruits and vegetables so that motivates children to consume them, children who initially do not like fruits and vegetables become like knowing the benefits. By the theory of the Health Belief Model, a person who feels the benefits of behaviour will influence his confidence to take action (Glanz, Rimer and Viswanath, 2008). Umbul Card Game is a traditional game that has generally been known since childhood through the home environment, community, or has been previously obtained in kindergarten, so it is more quickly captured and understood by students. Also, this will affect the students' inner feelings in the form of pleasant memories of the traditional game so that it certainly increases interest in learning (Erawati, Yogantara and Kiriana, 2019). Fun and enjoyment have been discussed related to the learning of children and older adults. Humour and fun can stimulate creative thought because the brain is more relaxed and is less bound by rules (Lucardie, 2014). The limitation of this study is that researchers have not been able to use images of personal work to be placed on the media for umbul card but use images on the internet (the source of the images in the bibliography). Researchers also only use a few students in class $\mathrm{V}$ as a validation of Umbul Card users. Then next researchers can use more students and involve students in grades IV and VI to make it possible to do statistical tests in the main field test (main field testing).

\section{REFERENCES}

BPOM. (2013). Pedoman Pangan Jajanan Anak Sekolah Untuk Pencapaian Gizi Seimbang (Pengawas dan/atau Penyuluh). Direktorat Standardisasi Produk Pangan, Deputi Bidang Pengawasan Keamanan 
Pangan dan Bahan Berbahaya, Badan Pengawas Obat dan Makanan RI, (23), 1-19.

Crosby, L., Jayasinghe, D. \& McNair, D. (2013). Food for thought: Tackling child malnutrition to unlock potential and boost prosperity. 1st edn. London: Save the Children.

Eliana, D. \& Solikhah. (2013). Pengaruh Buku Saku Gizi Terhadap Tingkat Pengetahuan Gizi Pada Anak Kelas 5 Muhammadiyah Dadapan Desa Wonokerto Kecamatan Turi Kabupaten Sleman Yogyakarta. Jurnal Kesehatan Masyarakat (Journal of Public Health), 6(2), 162-232. doi: 10.12928/kesmas.v6i2.1021.

Erawati, N. L., Yogantara, I. W., and Kiriana, I. N. (2019). Aplikasi Permainan TradisionalMapoh-Pohan Sebagai Metode Simulasi Pembelajaran Agama Hindu Dalam Meningkatkan Minat Belajar Siswa Kelas IV Di SD Negeri 5 Sumerta Denpasar. Jurnal Ilmu pendidikan, 2(2),. 368-383.

Fadhilah, D. (2017). Pengembangan Medıa Kartu Sayuran Sebagaı Media. Skripsi Politeknik kesehatan kemenkes yogyakarta.

Falahudin, I. (2014). Pemanfaatan Media dalam Pembelajaran Iwan Falahudin. Jurnal Lingkar Wisyaiswara, 1(4), 104-117. Available at: www.juliwi.com.

Glanz, K., Rimer, B. K., \& Viswanath, K. (2008). Health behavior and health education. 4th ed. Edited by K. Glanz, B. K. Rimer, \& K. Viswanath. Jossey Bass A Willey Brand. DOI: http://hdl.handle.net/2027/spo.10381607.0007.102.

Hamida, K., Zulaekah, S., \& Mutalazimah. (2012). Penyuluhan Gizi Dengan Media Komik Untuk Meningkatkan Pengetahuan Tentang Keamanan Makanan Jajanan. KESMAS - Jurnal Kesehatan Masyarakat, 8(1), 67-73. doi: 10.15294/kemas.v8i1.2261.

Hidayati, A. \& Ismail. (2018). Strategies to improve student learning habits for middle school student in sukoharjo, Indonesia. International Journal of Educational Research Review, 3(3), 74-79. doi: 10.24331/ijere.448762.

Isnardiantini, S., Usodo, B. \& Soegiyanto, H. (2019). The effect of discovery learning-based teaching material by utilizing traditional game on mathematic abilities of the 2nd graders of elementary school. Intrenational Journal of Educational Research Review, 4(3), 269-274.

Jin, G. et al. (2018). Evaluation of game-based learning in cybersecurity education for high school students. Journal of Education and Learning (EduLearn), 12(1), 150-158. doi: 10.11591/edulearn.v12i1.7736.

Jomaa, L. H., McDonnell, E. \& Probart, C. (2011). School feeding programs in developing countries: Impacts on children's health and educational outcomes. Nutrition Reviews, 69(2), 83-98. doi: 10.1111/j.17534887.2010.00369.x.

Komachali, M. E. \& Khodareza, M. (2012). The effect of using vocabulary flash card on iranian pre-university students " vocabulary knowledge. International Education Studies, 5(3), 134-147. doi: 10.5539/ies.v5n3p134.

Lucardie, D. (2014). The impact of fun and enjoyment on adult's learning. Procedia - Social and Behavioral Sciences. Elsevier B.V. 142, 439-446. DOI: 10.1016/j.sbspro.2014.07.696.

Marisa \& Nuryanto. (2014). Pengaruh Pendidikan Gizi Melalui Komik Gizi Seimbang Terhadap Pengetahuan Dan Sikap Pada Siswa Sdn Bendungan Di Semarang. Journal of Nutrition College, 3(4), 925-932. doi: 10.14710/jnc.v3i4.6911.

Mulyatiningsih, E. (2010). Pembelajaran Aktif, Kreatif Inovatif, Efektif dan, Menyenangkan (Paikem). Model Pembelajaran Aktif Inovatif Kreatif Efektif dan Menyenangkan. DI P4TIK Bisnis dan Pariwisata. doi: 10.1049/el:20057014.

Nurse, J. et al. (2014). The case for investing in public health. World Health Organization, 1-32.

Patria, A. S. \& Mutmainah, S. (2018). Using textbook 1llustration as media for developing character among primary students: Some research-based suggestion. Journal of Education and Learning (EduLearn), 12(1), 52-56. doi: 10.11591/edulearn.v12i1.6509. 
Perdana, F., Madanijah, S. \& Ekayanti, I. (2017). Pengembangan media edukasi gizi berbasis android dan website serta pengaruhnya terhadap perilaku tentang gizi seimbang siswa sekolah dasar. Jurnal Gizi dan Pangan, 12(3), 169-178. doi: 10.25182/jgp.2017.12.3.169-178.

Riskesdas. (2013). Hasil Riset Kesehatan Dasar. Badan Penelitian dan pengembangan Kesehatan Kementerian Kesehatan RI. doi: 10.1517/13543784.7.5.803.

Rohmah, N. \& Iriyani, K. (2016). Pendidikan Gizi Anak Sekolah Dasar Pada Daerah Hutan Hujan Tropis Kalimantan Timur. Higiene, 2(3), 121-125.

Rosso, J. M. D., \& Arlianti, R. (2009). Investing in school health and nutrition in Indonesia. Basic Education Capacity-Trust Fund, 1-37.

Santanu, G., Rakshit, S. \& Bhattacharya, M. (2013). Academic performance and nutritional status - a case study on college students in North Tripura. IOSR Journal of Research \& Method in Education (IOSRJRME), 1(4), 57-68. doi: 10.9790/7388-0145768.

Saputri, D. Y., Rukayah \& Indriayu, M. (2018). Need 65. International Journal of Educational Research Review, 3(3), 1-8. doi: 10.24331/ijere.411329.

Septiana, P. \& Suaebah (2018). Edukasi Media Kartu Bergambar Berpengaruh terhadap Pengetahuan Dan Sikap Anak Dalam Pemilihan jajanan Sehat di SD Negeri Pontianak Utara. Pontianak Nutrition Journal, $1(2), 56-59$.

Sunaengsih, C. (2016). Pengaruh Media Pembelajaran terhadap Mutu Pembelajaran pada Sekolah Dasar Terakreditasi A. Jurnal mimbar sekolah dasar, 3(2), 183-190. doi: 10.17509/mimbar-sd.v3i2.4259.

Wahidin, U. \& Syaefuddin, A. (2018). Media Pendidikan dalam Perspektif Pendidikan Islam. Jurnal Edukasi Islami Jurnal Pendidikan Islam, 7(1), 47-66. doi: 10.30868/EI.V7.

Wang, D. et al. (2018). Snacking patterns in children: A comparison between Australia, China, Mexico, and the US. Nutrients, 10(2), 1-14. doi: 10.3390/nu10020198.

Wedu, Z. R., Pamungkasari, E. P. \& Anantanyu, S. (2018). Nutrition Status affects High School Students achievement in: A massive prospective cohort study at Sleman, Yogyakarta Indonesia. Bali Medical Journal, 7(3), 617-620. doi: 10.15562/bmj.v7i3.973.

Zufriady, Z. \& Kurniaman, O. (2019). The effectiveness of learning basic concepts of art for primary teacher education students using nomor acak learning model. Mimbar Sekolah Dasar, 6(1), 32-42. doi: 10.17509/mimbar-sd.v6i1.15241.

Zulaekah, S. (2012). Pendidikan Gizi dengan Media Booklet Terhadap pengetahuan Gizi, Jurnal kesehatan masyarakat, 7(2), 127-133. 